\title{
PEMBERDAYAAN MASYARAKAT DALAM PENGELOLAAN SAMPAH SEBAGAI UPAYA PENANGANAN KAWASAN KUMUH DI KAWASAN PECANGAAN KABUPATEN JEPARA
}

\author{
Sri Subektia, Iwan Prayoga ${ }^{b}$, Agus Sarwo Edy Sudrajat $^{c}$ \\ aFakultas Teknik, Universitas Pandanaran, Semarang \\ Jl. Banjarsari Barat No. 1, Pedalangan, Banyumanik, Kota Semarang 50268 \\ bFakultas Teknik Sipil dan Perencanaan, Institut Teknologi Nasional, Yogyakarta \\ Jl. Babarsari, Tambak Bayan, Catur Tunggal, Kec. Depok, Kabupaten Sleman 55281 \\ 'Fakultas Teknik, Universtitas Semarang, Semarang \\ Jl. Soekarno Hatta, Tlogosari Kulon, Kec. Pedurungan, Kota Semarang 59160
}

Info Artikel:

- Artikel Masuk: 14/09/2020

- Artikel diterima: 15/10/2020

- Tersedia Online: 30/10/2020

\begin{abstract}
ABSTRAK (dalam Bahasa Indonesia)
Peningkatan urbanisasi dan pertambahan jumlah kawasan perumahan atau permukiman yang kurang tertata yang diiringi dengan dapat meningkatkan kekumuhan. Permukiman kumuh diartikan sebagai area permukiman yang tidak layak huni dengan kondisi bangunan yang tidak teratur, memiliki tingkat kepadatan bangunan yang tinggi, dengan kualitas bangunan serta sarana dan prasarana yang tidak memenuhi syarat. Permasalahan dari penelitian ini adalah rendahnya cakupan pelayanan persampahan dan bertambahnya volume sampah non organik yang sulit didaur ulang serta belum optimalnya tingkat kesadaran masyarakat tentang kebersihan merupakan masalah utama pengelolaan sampah. Tujuan dari penelitian ini adalah untuk mengatasi permasalahan persampahan sebagai upaya mencegah permukiman dari kekumuhan dan terciptanya masyarakat yang peduli terhadap pengelolaan sampah. Simpulan dari penelitian ini adalah perlunya pelayanan pengangkutan sampah ke TPS/TPA secara rutin sehingga kawasan Pecangaan menjadi lebih bersih, pengadaan tempat sampah setiap RT sehingga sampah dapar terwadahi dengan baik dan sarana prasarana untuk proses pengangkutan sampah, melakukan sosialisasi kepada masyarakat pada saat pertemuan warga mengenai pentingnya pengelolaan sampah yang dilakukan secara berkelanjutan, pemberian insentif bagi masyarakat/kelompok/wilayah yang mampu mengelola sampahnya dengan baik sebagai wilayah percontohan, memberikan pelatihan pada warga tentang pengelolaan sampah dengan konsep 3R (Reuse, Reduce, Recycle).
\end{abstract}

Kata Kunci : Kawasan Kumuh, Permukiman, Pengelolaan Sampah, Pemberdayaan Masyarakat

\begin{abstract}
Increased urbanization and the increase in the number of housing areas or settlements that are less organized, accompanied by increasing slums. Slum settlement is defined as a residential area that is unfit for habitation with irregular building conditions, has a high level of building density, with the quality of buildings and facilities and infrastructure that do not meet the requirements. The problem of this research is the low coverage of solid waste services and the increasing volume of nonorganic waste that is difficult to recycle and the level of public awareness about cleanliness is the main problem of waste management. The purpose of this research is to solve the problem of solid waste as an effort to prevent settlements from slums and to create a community that cares about waste management. The conclusion of this research is the need for regular waste transportation services to TPS / TPA so that the Pecangaan area becomes cleaner, the procurement of trash bins for each RT so that the waste can be well accommodated and the infrastructure for the process of transporting waste, socializing to the community at community meetings about the importance of waste management that is carried out in a sustainable manner, providing incentives for communities / groups / areas that are able to manage their waste properly as pilot areas, providing training to residents on waste management with the $3 R$ concept (Reuse, Reduce, Recycle).
\end{abstract}

Keyword: Slum Areas, Settlements, Waste Management, Community Empowerment

\section{PENDAHULUAN}

Seiring dengan peningkatan urbanisasi dan pertambahan jumlah kawasan perumahan dan/atau permukiman yang kurang tertata yang diiringi dengan dapat meningkatkan kekumuhan di kota-kota Bermukim di kawasan kumuh perkotaan bukan merupakan pilihan melainkan suatu keterpaksaan bagi kaum migran tak terampil yang harus menerima keadaan lingkungan permukiman yang tidak layak dan berada di bawah standard pelayanan minimal seperti rendahnya mutu pelayanan air minum, drainase, limbah, sampah serta masalahmasalah lain seperti kepadatan dan ketidak 
teraturan letak bangunan yang berdampak ganda baik yang berkaitan dengan fisik misalnya bahaya kebakaran maupun dampak sosial seperti tingkat kriminal yang cenderung meningkat dari waktu kewaktu.

Dilihat dari sisi pemanfaatan ruang permukiman, permukiman kumuh diartikan sebagai area permukiman yang tidak layak huni dengan kondisi bangunan yang tidak teratur, memiliki tingkat kepadatan bangunan yang tinggi, dengan kualitas bangunan serta sarana dan prasarana yang tidak memenuhi syarat. Penggunaan ruang para permukiman kumuh tersebut seringkali berada pada suatu ruang yang tidak sesuai dengan fungsi aslinya sehingga berubah menjadi fungsi permukiman, seperti muncul kantung-kantung permukiman pada daerah sempadan untuk kebutuhan ruang terbuka hijau atau lahan-lahan yang tidak sesuai dengan peruntukkannya (squatters).

Permukiman kumuh menjadi salah satu isu utama pembangunan perkotaan yang cukup menjadi polemik, karena upaya penanganan yang sebenarnya dari waktu ke waktu sudah dilakukan berbanding lurus dengan terus berkembangnya kawasan kumuh dan munculnya kawasan- kawasan kumuh baru. Secara khusus dampak permukiman kumuh juga akan menimbulkan paradigma buruk terhadap penyelenggaraan pemerintah, dengan memberikan dampak citra negatif akan ketidakberdayaan dan ketidakmampuan pemerintah dalam pengaturan pelayanan kehidupan hidup dan penghidupan warganya. Dilain sisi dibidang tatanan sosial budaya kemasyarakatan, komunitas yang bermukim di lingkungan permukiman kumuh secara ekonomi pada umumnya termasuk golongan masyarakat berpenghasilan rendah yang seringkali menjadi alasan penyebab terjadinya degradasi kedisiplinan dan ketidaktertiban dalam berbagai tatanan sosial masyarakat.

Permasalahan dari penelitian ini adalah rendahnya cakupan pelayanan persampahan dan bertambahnya volume sampah non organik yang sulit didaur ulang serta belum optimalnya tingkat kesadaran masyarakat tentang kebersihan merupakan masalah utama pengelolaan sampah.

Tujuan dari penelitian ini adalah untuk mengatasi permasalahan yang ditimbulkan dari persampahan sebagai salah satu upaya mencegah permukiman dari kekumuhan dan terciptanya masyarakat yang peduli terhadap pengelolaan sampah yang dihasilkan setiap harinya.

\section{DATA DAN METODE}

Metode penelitian yang dilakukan adalah dengan Studi Literatur, sebagai pendalaman materi atau teori untuk kawasn kumuh dan persampahan. Mengumpulkan data primer dan sekunder terkait issue strategis, potensi dan permasalahan kawasan kumuh dan persampahan.

\section{HASIL DAN PEMBAHASAN}

Timbulan sampah adalah banyaknya jumlah sampah yang dihasilkan pada suatu wilayah per orang per hari dalam satuan volume ataupun berat. Untuk memperoleh data jumlah sampah guna menghitung jumlah timbulan sampah di suatu lokasi wilayah / kawasan, maka harus mengetahui sumber atau penghasil sampah yang ada.

Timbulan sampah yang dihasilkan dari wilayah perkotaan salah satunya berasal dari sampah yang berasal dari kawasan permukiman, pasar, sarana jalan, kemudian fasilitas pelayanan umum. Pengelolaa sarana persampahan pada suatu wilayah atau daerah ditangani oleh Institusi Formal Pengelola Sampah dan biasanya langsung ditangani oleh Pemerintah Daerah di bawah Bagian Dinas Kebersihan. Dinas Kebersihan yang mempunyai tugas utama sebagai Organisasi Pelaksanaan Rutin mempunyai Struktur Organisasi Pengelolaan Sampah sendiri.

Komposisi sampah di Pecangaan menghasilkan jumlah sampah terbesar yang berasal dari sisa makanan yang mudah membusuk seperti sayur, buah-buahan, sisa nasi dll. Komposisi sampah ini perlu diketahui jumlah maupun komponennya sehingga dapat menentukan jenis sampah dan sistem pengelolaannya, karena hal ini nantinya akan membawa pengaruh terhadap sistem penampungan sampah yang paling sesuaikemudian bagaimana sistem pengangkutannya dan sistem pemusnahannya. Selain hal tersebut di atas dapat juga digunakan 
sebagai dasar untuk menyesuaikan dengan tipe peralatan penampung dan pengangkutnya serta tipe peralatan pendukung dan metode pemusnahannya.

Pemberdayaan maasyarakat dalam suatu proses kegiatan adalah proses dimana masyarakat mempunyai beberapa tolok ukur atau suatu inisiatif untuk memulai suatu kegiatan sosial dengan maksud sebagai suatu sarana untuk memperbaiki situasi dan kondisi. Hal ini bisa berjalan dengan maksimal jika masyarakat ikut berpartisipasi aktif dalam semua kegiatan dengan tujuan untuk menghasilkan wilayah yang bersih dan berwawasan lingkungan.

Pemberdayaan dapat juga diartikan sebagai suatu proses untuk mengembangkan, menjadikan warga lebiah mandiri atau menjadikan suatu swadaya pada masyarakat sebagai upaya memperkuat posisi pada masyarakat lapisan bawah terhadap kekuatan atau penekan pada suatu kawasan di segala bidang dan sektor kehidupan (Sutoro Eko, 2002).

Dalam suatu upaya untuk melakukan suatu kegiatan yang melibatkan masyarakat maka perlu suatu kajian atau strategi pemberdayaan masyarakat dengan tujuan nantinya dapat meningkatkan kesejahteraan hidup masyarakat. Adapun strategi yang dipakai untuk agar pemberdayaan masyarakat dapat berjalan dengan maksimal maka dilakukan suatu proses pendampingan. Menurut Sumodiningrat (2009:106), pendampingan adalah suatu kegiatan yang diyakini akan mampu untuk mendorong terjadinya pemberdayaan secara optimal. Proses ini perlu dilakukan karena kegiatan pendampingan ini dilatarbelakangi adanya beberapa kesenjangan pemahama antara pihak yang memberikan bantuan dengan sasaran penerima bantuan. Kesenjangan yang timbul disebabkan antara lain karena adanya perbedaan dan keterbatasan pada kondisi sosial, karakteristik budaya dan perekonomian. Dalam melaksanakan tugasnya, para pendamping bertugas sebagai perencana, pembimbing, pemberi informasi, motivator, penghubung, fasilitator, dan sekaligus evaluator.

Menurut Permendagri Republik Indonesia Nomor 7 Tahun 2007 tentang Kader Pemberdayaan Masyarakat, dinyatakan bahwa pemberdayaan masyarakat adalah suatu strategi yang digunakan dalam pembangunan masyarakat sebagai upaya untuk mewujudkan kemampuan dan kemandirian dalam kehidupan bermasyarakat, berbangsa dan bernegara (Pasal 1, ayat (8)). Dengan melibatkan masyarakat diharapkan kegiatan pemilahan sampah yang menjadi kunci pokok dari pengelolaan sampah dapat berjalan dengan maksimal. Untuk mencapai hasil maksimal, dapat melibatkan warga masyarakat yang mempunyai keahlian pada bidang tertentu sehingga akan lebih memahami konsep pengelolaan sampah dengan harapan nantinya dapat berkelanjutan.

Kabupaten Jepara memiliki luas wilayah 100.413.189 $\mathrm{Ha}$ yang terbagi menjadi 16 Kecamatan dengan luasan yang beragam. Adapun luas wilayah Pecangaan 35.339 km2 dengan jumlah Desa/ Kelurahan sejumlah 12 Desa, dengan 71 RT dan 345 RW. Adapun jumlah penduduk di Wilayah Pecangaan dapat di lihat pada tabel di bawah ini.

Tabel 1. Perkiraan Jumlah Timbulan Sampah Per Hari (hasil analisis, 2018)

\begin{tabular}{cccc}
\hline $\begin{array}{c}\text { Lokasi } \\
\text { TPA }\end{array}$ & $\begin{array}{c}\text { Melayani } \\
\text { Kecamatan }\end{array}$ & $\begin{array}{c}\text { Jumlah } \\
\text { Penduduk } \\
\text { (Jiwa) }\end{array}$ & $\begin{array}{c}\text { Timbulan } \\
\text { Sampah } \\
\text { (kg/hari) }\end{array}$ \\
\hline \multirow{3}{\text{TPA}}{$\begin{array}{c}\text { Pecangaan, } \\
\text { Kalinyamatan, } \\
\text { Wemulung } \\
\text { Mayong }\end{array}$} & 315.049 & 220.534 \\
& & \\
\hline
\end{tabular}

Dari tabel di atas terlihat adanya perkiraan timbulan sampah yang di buang ke TPA Gemulung setiap harinya, dengan pelayanan mencakup pada Kecamatan Pecangaan, Kecanatan Kalinyamatan. Dengan volume sampah yang sedemikian banyak jika tidak terdapat pengelolaan sampah yang salah satunya adalah pemilahan sampah dai rumah tangga maka TPA Gemulung akan cepat penuh.

Timbulan sampah merupakan banyaknya sampah yang dihasilkan per orang per hari dalam satuan volume ataupun berat. Untuk memperoleh data / menghitung jumlah timbulan sampah di suatu lokasi wilayah / kawasan, maka perlu diketahui terlebih dahulu sumber penghasil sampah yang ada.

Sistem pengelolaan persampahan yang tepat dapat meningkatkan kualitas lingkungan. 
Dalam sistem pengelolaan persampahan terdapat beberapa indikator yang dipertimbangan yaitu prasarana dan sarana yang sesuai dengan persyaratan teknis mencakup tempat sampah skala rumah tangga, tempat pengumpulan sampah (TPS), gerobak sampah atau truk sampah dan tempat pengolahan sampah terpadu. Sistem pengelolaan persampahan harus memenuhi persyaratan antara lain pewadahan dan pemilahan domestik, pengumpulan, pengangkutan, dan pengolahan lingkungan. Ketersediaan prasarana dan sarana harus diimbangi dengan pemeliharaannya karena dapat mempertahankan sistem pengelolaan persampahan yang stabil.

Pada Ibukota Kecamatan Pecangaan yaitu Desa Pecangaan Kulon yang tidak menerapkan sistem pengelolaan persampahan yang sesuai dengan persyaratan teknis. Desadesa tersebut adalah Dibuktikan dengan tidak ada rumah tangga yang menerapkan sistem pengelolaan persampahan yang sesuai dengan persyaratan. Bagi desa lainnya terdapat beberapa rumah tangga yang menerapkan pengelolaan persampahan yang sesuai teknis. Sebanyak 475 rumah tangga yang menerapkan sistem pengelolaan persampahan, jika dipersentasekan hanya sekitar 3,6\%.

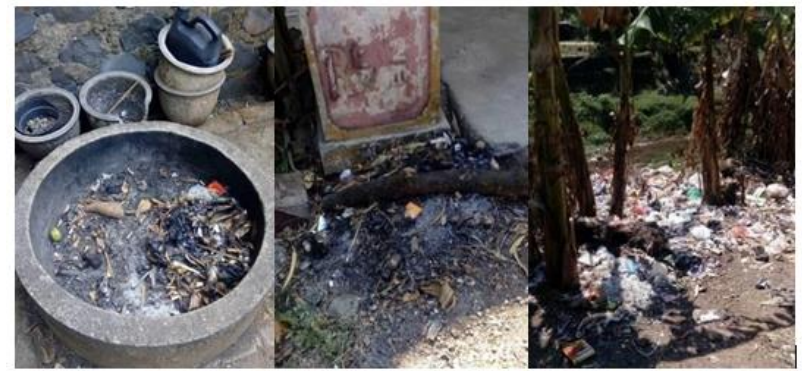

Gambar 1. Kondisi Persampahan di Wilayah Pecangaan (dokumentasi, 2018)

Dari gambar di atas terlihat bahwa sampah di Wilayah Pecangaan dengan kondisi sampah masih berserakan dan dibuang tidak pada tempatnya, dengan kondisi tersebut jelas terlihat belum terkelolanya sampah dengan aikdengan baik. Kondisi sepertti ini memberikan dampak negative pada lingkungan, sehingga menurunkan tingkat estetika, dapat memberikan dampak terhadap kesehatan manusia.
Tabel 1. Jumlah Rumah Tangga yang Terlayani Akses Persampahan (BPS, 2018)

\begin{tabular}{|c|c|c|c|c|}
\hline Kecamatan & No. & Desa & $\begin{array}{c}\text { Jumlah } \\
\text { RT }\end{array}$ & $\begin{array}{c}\text { Jumlah } \\
\text { Sampah } \\
\text { Domestik } \\
\text { Terangkut } \\
\text { Min. 2X } \\
\text { Seminggu } \\
\text { (Unit RT) } \\
\end{array}$ \\
\hline \multirow[t]{7}{*}{ Pecangaan } & 1 & Krasak & 1.607 & 182 \\
\hline & 2 & Lebuawu & 1.122 & 119 \\
\hline & 3 & $\begin{array}{l}\text { Pecangaan } \\
\text { Kulon }\end{array}$ & 1.725 & 0 \\
\hline & 4 & $\begin{array}{l}\text { Pecangaan } \\
\text { Wetan }\end{array}$ & 877 & 135 \\
\hline & 5 & Pulodarat & 1.231 & 28 \\
\hline & 6 & Rengging & 1.613 & 0 \\
\hline & 7 & Troso & 5.106 & 11 \\
\hline \multicolumn{3}{|c|}{ Jumlah } & 13.281 & 475 \\
\hline
\end{tabular}

Dari tabel di atas terlihat bahwa jumlah rumah tangga yang terlayani di lbukota Kecamatan Pecangaan paling banyak RT nya terdapat di Desa Troso dengan jumlah 5.106 RT. Jumlah tersebut nantinya dapat berpengaruh terhadap proses pengangkutan sampah.

Sampah adalah limbah yang bersifat padat terdiri dari zat organik dan zat anorganik yang dianggap tidak berguna lagi dan harus dikelola agar tidak membahayakan lingkungan dan melindungi investasi pembangunan (Anonim,1990). Sampah adalah bahan buangan sebagai akibat aktivitas manusia dan hewan, yang merupakan bahan yang sudah tidak berguna lagi, sehingga dibuang sebagai barang yang tidak berguna (Sudarso, 1985)

Sampah adalah istilah yang umum untuk menyatakan limbah padat yang sudah tidak digunakan lagi dan langsung terbuang. Sampah adalah sisa-sisa bahan yang mengalami perlakuan-perlakuan, baik karena telah diambil bagian utamanya, atau karena pengolahan, atau karena sudah tidak ada manfaatnya yang ditinjau dari segi sosial ekonamis tidak ada harganya dan dari segi lingkungan dapat 
menyebabkan pencemaran atau gangguan terhadap lingkungan hidup (Hadiwiyoto, 1983)

Kriteria pengukuran suatu sistem persampahan dikatakan baik dilihat dari ketersediaan sarana dan prasarana persampahan yang sesuai dengan persyaratan teknis seperti tempat sampah, TPS, gerobak sampah, dan tempat pengolahan sampah. Sistem pengelolaan persampahan yang terdiri dari pewadahan, pemilahan domestik, pengangkutan, pengumpulan dan pengolahannya. Selain itu tidak hanya ketersediaannya saja namun juga pemeliharaan sarana dan prasarana persampahan.

Sesuai dengan peraturan di dalam Undang Undang No. 18 tahun 2008 tentang Pengelolaan Sampah yang tercantum pada $\mathrm{Bab}$ I pasal 1 ayat 3 bahwa yang dimaksud dengan pengelolaan sampah merupakan kegiatan yang sistematis, berkelanjutan yang terdiri dari kegiatan pengurangan dan penanganan. Proses pengurangan merupakan upaya untuk mengurangi jumlah sampah yang akan diangkut dan diproses di tempat pemrosesan akhir sampah. Pendekatan pengelolaan sampah seyogyanya dilakukan melalui pendekatan berbasis 3R dan berbasis masyarakat, pengelolaan sampah secara terpadu dengan melaksanakan pengelolaan sejak dari sumbernya. 3R adalah upaya yang meliputi kegiatan mengurangi (reduce), menggunakan kembali (reuse) dan mendaur ulang sampah (recycle).

Kegiatan dari suatu proses pengurangan sampah dapat dimulai, misalnya dengan cara membatasi timbulan sampah, proses mendaur ulang sampah kemudian bisa juga dengan memanfaatkan kembali sampah. Pada kegiatan pemilahan sampah merupakan kegiatan paling utama pada proses mendaur ulang sampah dimana kegiatan ini harus disesuaikan dengan jenis dan sifat dari sampah sampai ke tahap pengumpulan dari sumbe sampah sampai nantinya ke Tempat Pembuangan Sementara. Proses dari semua ini nantinya sampai pada tahapan pengangkutan dari sumber yang di bawa ke tempat pemrosesan sampah.

Dengan berpatokan pada undangundang, penanganan permukiman kumuh diawali dengan identifikasi lokasi permukiman kumuh dan penetapan lokasi permukiman kumuh tersebut melalui SK Walikota/Bupati. Melalui identifikasi tersebut, penanganan dilakukan sesuai Undang-Undang Nomor 1 tahun 2011 tentang Perumahan dan Kawasan Permukiman berbagai hal tentang pemeliharaan dan perbaikan kawasan permukiman, serta pencegahan dan peningkatan kualitas perumahan dan permukiman kumuh dengan tiga pola penanganan yaitu pemugaran, peremajaan dan pemukiman kembali.

Permukiman sering disebut perumahan dan atau sebaliknya permukiman berasal dari kata housing dalam Bahasa Inggris yang artinya adalah perumahan dan kata human settlement yang artinya adalah permukiman. Perumahan memberikan kesan tentang rumah atau kumpulan rumah beserta prasarana dan sarana lingkungan. Perumahan menitik beratkan pada fisik atau benda mati, yaitu house dan land settlement. Permukiman memberikan kesan tentang pemukiman atau kumpulan pemukim beserta sikap dan perilakunya di dalam lingkungan, sehingga permukiman menitikberatkan pada sesuatu yang bukan bersifat fisik atau benda mati yaitu manusia (human). Dengan demikian perumahan dan permukiman merupakan dua hal yang tidak dapat dipisahkan dan sangat erat hubungannya, pada hakikatnya saling melengkapi (Kurniasih,2007).

Untuk mencapai tujuan agar wilayah menjadi lebih bersih dan tertata maka kegiatan pembangunan pada sector kebersihan diarahkan pada pengelolaan sampah yang terintegrasi dalam sistem pengelolaan terpadu dan ramah lingkungan untuk menjamin daya dukung pembangunan yang berkelanjutan.

Pengelolaan sampah merupakan suatu aktifitas yang sistematis dan perlu suatu berkesinambungan dalam upaya pengelolaan sampah meliputi pengurangan dan penanganan sampah. Pengelolaan sampah berbasis masyarakat melalui pola $3 R$, perlu dioptimalkan di dalam penerapannya karena program ini berkaitan dengan kebijakan dan strategi nasional pengembangan pengelolaan persampahan terutama berkaitan dengan kebijakan pengurangan sampah sejak dari sumbernya, sesuai yang diamatkan dalam UU No 18 Tahun 2008, tentang Pengelolaan Sampah dan Permen PU No 21/PRT/M/2006, 
tentang kebijakan dan Strategi Nasional Pengembangan Persampahan.

Upaya kegiatan 3R membutuhkan partisipasi aktif seluruh stakeholders yang terkait dengan masalah persampahan. Mengingat upaya pengurangan volume sampah di sumber sangat erat kaitannya dengan perilaku masyarakat, diperlukan suatu upaya penyadaran dan peningkatan pemahaman untuk mendorong perubahan perilaku yang dilakukan secara berjenjang, baik melalui promosi atau diseminasi maupun kampanye yang terus menerus. Desiminasi dan sosialisasi penanganan 3R menjadi sangat penting dalam pengelolaan sampah, perlu dilakukan terusmenerus kepada setiap strata lapisan masyarakat baik secara individu maupun kelompok, dengan menggunakan bahasa, sarana-prasarana dan media yang sesuai dengan target kelompok yang dituju.

Beberapa upaya untuk pengurangan sampah yang di mulai dari sumbernya perlu diberikan suatu dukungan, misalnya dengan memberikan insentif yang dapat mendorong masyarakat untuk senantiasa melakukan kegiatan 3R. Pemberian insentif bisa diberikan antara lain dalam bentuk memberi pengurangan pada retribusi sampah setiap bulannya, memberikan kupon sebagai pengganti kantong plastik atau dengan memberikan penghargaan tingkat kelurahan,dll, dan semua kegiatan tersebut tentunya diawali dengan kesiapan pengelolaan sampah pada wilayah Pecangaan.

\section{SIMPULAN}

Perlunya pelayanan pengangkutan sampah ke TPS/TPA secara rutin sehingga kawasan Pecangaan menjadi lebih bersih. Pengadaan tempat sampah setiap RT sehingga sampah dapar terwadahi dengan baik dan sarana prasarana untuk proses pengangkutan sampah. Melakukan sosialisasi kepada masyarakat pada saat pertemuan warga mengenai pentingnya pengelolaan sampah yang dilakukan secara berkelanjutan. Pemberian insentif bagi masyarakat/kelompok/wilayah yang mampu mengelola sampahnya dengan baik sebagai wilayah percontohan. Memberikan pelatihan pada warga tentang pengelolaan sampah dengan konsep 3R (Reuse, Reduce, Recycle)

\section{REFERENSI}

Hadiwiyoto, 1983 Penanganan dan Pemanfaatan Sampah, Penerbit: Yayasan Idayu Jakarta.

Kurniasih 2007 Usaha Perbaikan Permukiman Kumuh di Pertukangan Utara Jakarta Selatan. Jurnal Fakultas Teknik Universitas Budi Luhur.

Permendagri RI Nomor 7 Tahun 2007 tentang Kader Pemberdayaan Masyarakat.

Permen PU No 21/PRT/M/2006, tentang kebijakan dan Strategi Nasional Pengembangan Persampahan.

Sudarso, 1985 Pembuangan Sampah Penerbit: CV Tiga Serangkai Surabaya.

Sutoro Eko, 2002 Pemberdayaan Masyarakat Desa Penerbit Alfabeta Bandung.

Undang-Undang Nomor 1 tahun 2011 tentang Perumahan dan Kawasan Permukiman.

Undang - Undang Nomor 18 Tahun 2008 tentang Pengelolaan Sampah.

Undang - Undang Nomor 32 Tahun 2009 tentang Perlindungan dan Pengelolaan Lingkungan Hidup. 